\title{
ECtHR RETROACTIVE JURISDICTION AND THE POSSIBILITY OF COMPENSATIONS FOR THE ARMENIAN PROPERTIES CONFISCATED DURING AND AFTER THE ARMENIAN GENOCIDE: A BRIEF ANALYSIS ${ }^{1}$
}

\author{
Hasmik Tigranyan \\ Edita Gzoyan
}

This article examines retroactive jurisdiction of the European Court of Human Rights (ECtHR) for the possibility to litigate compensations for the Armenian properties confiscated during and after the Armenian Genocide. The study considers ECtHR platform for the Armenian Genocide reparations, as ECtHR is the most effective human rights regional Court to compel Turkey to protect human rights and remedy for violations. The paper considers only European Convention on Human Rights (Convention) Article 1 Protocol 1 to avoid as much as possible politicizing this study. Considering the fact that long time has passed since the confiscations, this study considers ratione temporis jurisdiction of the ECtHR.

Key words: reparations, compensations, European Court of Human Rights (ECtHR), European Convention on Human Rights (Convention), confiscation, abandoned property.

\section{Introduction}

In 1915 the Ottoman Empire implemented the most heinous plan of annihilation of its Armenian population. Alongside with systematic and organized massacres, deportations and assimilations Armenians were being deprived of their properties. Dispossession of the Armenian community was a part of government policy to change the ethnic composition of the Ottoman Empire. ${ }^{2}$ The government enacted a series of laws and decrees to deal with the issue of abandoned property known as the Abandoned Properties Laws. The laws legalized the liquidation of the Armenian properties and the settlement of Muslim migrants on those properties. Meanwhile, it should be mentioned that the Abandoned Properties Law (also the Deportation law) was enacted retroactively, intended to justify the illegal actions of the Ottoman government in view of possible future demands for retribution. ${ }^{3}$

Initially Armenians were assured by the Turkish government that they would be provided with equivalent values of their seized properties and measures would be taken to safeguard their property rights. However, situation was completely different on the ground: Armenian properties were sold, auctioned and/or transferred to others, while the government continued to assure that it was administering the properties in the name of its original owners. ${ }^{4}$

\footnotetext{
1 The article was received on 10.01.2020 and accepted for publication on 01.10.2020.

2 Hilmar Kaiser's "Armenian Property, Ottoman Law and Nationality Policies during the Armenian Genocide, 1915-1916," in Olaf Farschid et al, The World War I as Remembered in the Countries of the Eastern Mediterranean (Beirut: Orient-Institute Beirut, 2006), 64.

3 Ibid., 70.

4 On the issue of the confiscation see: Gözel Durmaz, "The Distribution of the Armenian Abandoned Proper-
} 
The situation continued also during the Turkish Republic - the continuing state of the Ottoman Empire. ${ }^{5}$ Although after WWI the new Turkish government rejected and reversed the Abandoned Properties Laws, however, the new nationalistic government of Turkey led by Mustafa Kemal abolished those laws, reinstating the old ones. The Kemalist Government seized all the Armenian properties and rejected the return of Armenians and reclamation of their properties. ${ }^{6}$

A general principle of international law stipulates that wrongful acts and injuries caused by those acts made by the state put responsibility to provide reparation. The principle was reiterated by Permanent Court of International Justice stating that "It is a principle of international law that the breach of an engagement involves an obligation to make reparation in an adequate form."' Though approximately a century has passed from those notorious events this issue is still urgent. Nowadays descendants of the Armenian Genocide survivors, as their legal successors, are still trying to seek appropriate remedies for restoration of their violated rights.

Today the Republic of Turkey is an active member of the international community and party to different international treaties, under which it takes some obligations to implement. The Republic ratified the European Convention on Human Rights (hereinafter Convention) in $1954,{ }^{8}$ although recognized the compulsory jurisdiction of the European Court of Human Rights (hereinafter ECtHR) in $1990 .{ }^{9}$

The right of individual petition is accurately considered as the greatest achievement of individuals who consider their human rights have been violated to lodge a complaint before the ECtHR. There are, however, important admissibility requirements (admissibility criteria) set out in the ECtHR that must be satisfied for the case examination.

The ECtHR standing and admissibility criteria are set in Article 34 and Article 35 of the Convention. One of these criteria is compatibility ratione temporis for admissibility relating to ECtHR's jurisdiction. Because the actual confiscations have occurred nearly 100 years

ties in an Ottoman Locality: Kayseri (1915-18)," Middle Eastern Studies 51, no. 5 (2015): 838-885; Bedross Der Matossian, "The Taboo within the Taboo: The Fate of 'Armenian Capital' at the End of the Ottoman Empire," European Journal of Turkish Studies, Complete List (2011), at http://journals.openedition.org/ejts/4411, accessed 20.11.2019; Uğur Ümit Üngör and Mehmet Polatel, Confiscation and Colonization: The Young Turk Seizure of Armenian Property (London, New York: Continuum, 2011); Levon Marashlian, "Finishing the Genocide: Cleansing Turkey of Armenian Survivors, 1920-1923," in Remembrance and Denial: The Case of the Armenian Genocide, ed. Richard Hovannisian (Detroit: Wayne State University Press, 1999): 113-145; Kévork Baghdjian, La Confiscation, par le gouvernement turc, des biens arméniens...dits "abandonnés», (Montreal: s.

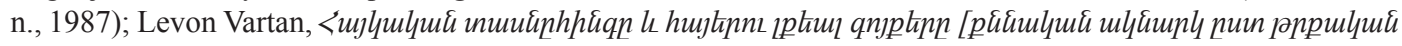
luılknuqptinnı] [The Armenian 15 and the Abandoned Properties of the Armenians: Critical Commentary according to the Turkish Documents] (Beirut: Atlas, 1970), etc.

5 On the issue of the state secession see e.g. Emre Ökmen, "Turkey: Successor or Continuing State of the Ottoman Empire?” Leiden Journal of International Law 24, no. 1 (2011): 561-583; Patrick Dumberry, “The Consequences of Turkey Being the 'Continuing' State of the Ottoman Empire in Terms of International Responsibility for Internationally Wrongful Acts,” International Criminal Law Review 14 (2014): 261-273.

6 Üngör and Polatel, Confiscation and Colonization, 49-59.

7 Factory at Chorzow (Germ. v. Pol.), 1927 P.C.I.J. (ser. A) No. 9 (July 26), para. 55.

8 See e.g. at https://www.Convention.coe.int/Documents/CP_Turkey_ENG.pdf, accessed 21.11.2019.

9 Frédéric Mégret, “The Notion of 'Continuous Violations', Expropriated Armenian Properties, and the European Court of Human Rights,” International Criminal Law Review 14 (2014): 317-331. 
ago, and ratione temporis criteria seem to be the most problematic in the Armenian case, the article considers only ratione temporis jurisdiction issue.

As is the case in most court proceedings, time is a crucial element for anyone who wants to apply to ECtHR. Time factor poses restrictions on the possibility to bring a claim to ECtHR, in respect of the admissibility of the claim as well as the jurisdiction of ECtHR. In both cases the concept of continuing violations/continuing situations can have a softening effect on the established strict procedural limitations. The birth of the concept of "continuing violations" was connected with the human disappearance cases considered by the Inter-American Court of Human Rights despite the lack of ratione tempori jurisdiction. ${ }^{10}$ This approach was also taken by the ECtHR, which for the first time recognized the existence of continuing situation in the case of De Becker v Belgium in 1958. ${ }^{11}$ Another instance when the concept was used was connected with the expropriation cases. Despite a general approach by the ECtHR that expropriation cases are predominantly instantaneous acts, ${ }^{12}$ in certain cases they can be viewed as continuing violation when deprivation "manifest itself in some specific fashion." 13

The article will firstly examine compatibility ratione temporis for the jurisdiction of the ECtHR and analyze cases on court's retroactive jurisdiction. Then the article will examine Turkish laws, decrees and orders related to the Armenian properties. Finally, the article will apply ECtHR case law on the Armenian properties confiscations case to find whether the continuing situation/continuing violation can be applied.

\section{ECtHR Ratione Temporis Admissibility Criteria}

In accordance with a general principle of non-retroactivity of treaties, the provisions of the Convention "do not bind a Contracting Party in relation to any act or fact which took place or any situation which ceased to exist before the date of the entry into force of the Convention in respect of that Party." 14

Jurisdiction ratione temporis covers only a period after the ratification of the Convention or its Protocols ${ }^{15}$ and imposes no specific obligation on member states to provide redress for wrongs or damage caused prior to that date. ${ }^{16}$ However, after the ratification date,

10 The reasoning was that disappearances were assessed as continuing violation before discovering circumstances of the disappeared person. For more on this see Mégret, "The Notion of Continuous Violations."

11 De Becker v. Belgium, App. No. 214/56, [1958-59] Y.B.

12 Case of Posti and Rahko v. Finland, no. 27824/95, Judgement, 21.05.2003, paras. 39, 40, 46; Kotov v. Russia, no. 54522/00, Judgement, 03.04.2012, paras. 63, 66, 67.

13 Mégret, "The Notion of Continuous Violations," 321

14 European Court of Human Rights, Practical Guide on Admissibility Criteria (Updated on 30 April 2020), p. 46, at http:/www.Convention.coe.int/Documents/Admissibility_guide_ENG.pdf, 47, accessed 02.11.2019; see also Blečić v. Croatia, no. 59532/00, Judgement, 08.03.2006, para. 70; Varnava and Others v. Turkey, nos. 16 064/90, 16065/90, 16066/90, 16068/90, 16069/90, 16070/90, 16071/90, 16072/90 and 16073/90, Judgement, 18.09.2009, para. 130.

15 Since its adoption in 1950 the Convention has been amended a number of times and supplemented with many rights in addition to those set forth in the original text. As of now there are 16 Protocols.

16 Practical Guide on Admissibility Criteria, 59; see also Kopecký v. Slovakia, no. 44912/98, Judgement, 28.06.2004, para. 38 . 
all the acts and omissions of the contracting states must be in accordance to the Convention and its Protocols and, consequently, all following facts fall within the jurisdiction of the ECtHR even if they are "merely extensions of an already existing situation." ${ }^{17}$ ECtHR may, however, consider facts prior to the ratification date "inasmuch as they could be considered to have created a situation extending beyond that date or may be relevant for the understanding of facts occurring after that date." 18 Moreover, the ECtHR has an obligation on its own motion to examine its ratione temporis jurisdiction at any stage of the proceedings. ${ }^{19}$

The European Commission on Human Rights (hereinafter Commission) and the ECtHR have accepted the extension of their jurisdiction ratione temporis to situations involving a continuing violation. As already mentioned the concept arose with regard to human disappearances. According to the ECtHR disappearance is not an "instantaneous" act or event but a "distinct phenomenon," marked by uncertainty and unaccountability, where there is a lack of information or a willful concealment of what has happened to a person. The failure to provide about the whereabouts and fate of the missing person gives rise to a continuing situation. Consequently, the obligation to investigate into the happening will remain as long as the fate of the disappeared person remains unknown and the failure for such investigation will be regarded as a continuing violation..$^{20}$ In another instance the concept was used with regard to the right of property. In some cases the ECtHR has recognized continuing violations of the right to property when "the deprivation could be said to have manifested itself in some specific fashion." The jurisprudence of the ECtHR on the issue began in the mid-1990s relating to Greece and Turkey, and later included cases against the states of the former Eastern Bloc. ${ }^{21}$ Particularly, ECtHR has stated having temporal jurisdiction in the following cases:

- denial of access to the applicant's property in Northern Cyprus; ${ }^{22}$

- continuing unlawful occupation without compensation by the navy of land that belong to the applicants, ${ }^{23}$

- continuing impossibility to regain possession of the property and receive an adequate level of rent because of the Polish laws in force before and after ratification of Protocol 1 by Poland; ${ }^{24}$

- failure to pay final compensation for the property that was nationalized; ${ }^{25}$

- continued non-enforcement of a domestic decision in the applicant's favor against the State. ${ }^{26}$

17 Practical Guide on Admissibility Criteria, 59; see also Almeida Garrett, Mascarenhas Falcão and Others $v$. Portugal, nos. 29813/96 and 30229/96, Judgement, 11.01.2000, para. 43.

18 Practical Guide on Admissibility Criteria; see e.g. Hutten-Czapska v. Poland, no. 35014/97, Judgement, 19.06.2006, paras. 147-153.

19 Practical Guide on Admissibility Criteria, 59.

20 Varnava and Others v. Turkey, paras.148-149.

21 Mégret, "The Notion of Continuous Violations," 321.

22 Loizidou v. Turkey, no. 15318/89, Judgement, 18.12.1996, paras. 46-47.

23 Papamichalopoulos and Others v. Greece, no. 14556/89, Judgement, 24.06.1993, para. 40.

24 Hutten-Czapska v. Poland, no. 35014/97, Judgement, 19.06.2006, paras. 152-153.

25 Almeida Garrett, Mascarenhas Falcão and Others v. Portugal, nos. 29813/96 and 30229/96, Judgement, 11.01.2000.

26 Krstić v. Serbia, no. 45394/06, Judgement, 10.03.2014, paras. 63-69. 
Meanwhile it should be noted that the mere deprivation of a property is considered to be an "instantaneous act" without producing a continuing situation.

Thus, the ECtHR can apply retroactive jurisdiction if continuing situation/violation is established. In order to deeply understand the nature of continuing violation and apply it to Armenian properties case, this article bellow will present a deep analysis of continuing situations regarding property confiscation generally and the ECtHR practice in this regard.

\section{Continuing Situation/Violation Analysis: Expropriation}

In its Commentary on the Articles on the Origin of State Responsibility the International Law Commission of the United Nations (I.L.C.) described a "continuing act" as "one which is a single act extending over period of time and of a lasting nature." ${ }^{27}$ Also the I.L.C. has defined a "continuing act" as one "which proceeds unchanged over period of time: in other words an act which, after it occurs continues to exist as such and not merely in its effects and consequences." While an instantaneous act is "an act that does not extend in time, i.e. act that ends as soon as committed; where the breach have occurred also automatically ceases to exist." ${ }^{28}$

According to the Articles on State Responsibility of I.L.C's, "acts that constitute continuing violations of international law, distinguishable from instantaneous acts, are not only "acts which continue in time" but also composite acts which consists of sequence of separate courses of conduct, actions or omissions adopted in separate cases, but all contributing to the commission of the aggregate act in question. ${ }^{\prime 29}$

In more details the following are three categories of alleged breaches by the state of its international obligations that differ from instantaneous acts:

- Situations that are act with a continuing character;

- Composite acts, those "composed of a series of actions or omissions in respect of separate cases";

- Complex acts, constituted by actions or omissions by the same or different organs of the state in respect of the same case. ${ }^{30}$

The ECtHR and the Commission has accepted this line and have acknowledged continuing situations in the same three categories. ${ }^{31}$ Under the first category are simple continuing situations that usually started at an identifiable date and continued until the situation ceases to exist (e.g. detentions and legislative provisions that remain in force). Second are complex acts which are composed of a series of consecutive acts. The third one is composite acts (concerning the "reasonable time" of proceedings before civil courts). Here ECtHR concluded:

27 Document A/33/10, Report of the International Law Commission on the work of its Thirtieth session, 8 May - 28 July 1978, Official Records of the General Assembly, Thirty-third Session, Supplement No. 10, p. 90-97 at https://legal.un.org/ilc/documentation/english/reports/a_33_10.pdf, accessed 30.11.2019.

28 Ibid., 88, 90-97.

29 Ibid., 92.

30 Draft Articles on State Responsibility with Commentaries Thereto Adopted by the International Law Commission on First Reading (1997), 97-98.

31 Andy Van Pachtenbeke and Yves Haeck, "From De Becker to Varnava: the state of continuing situations in the Strasbourg case law," European Human Rights Law Review 1 (2010): 47-59. 
The frequency with which violations are found shows that there is an accumulation of identical breaches which are sufficiently numerous to amount not merely to isolated incidents. Such breaches reflect a continuing situation that has not yet been remedied and in respect of which litigants have no domestic remedy. This accumulation of breaches accordingly constitutes a practice that is incompatible with the Convention. ${ }^{32}$

Moreover, according to the Commission continuing nature of violations of human rights is considered to be an aggravating factor. ${ }^{33}$ In other international instruments and resolutions continuing nature of human rights violations is qualified as "systematic," "constant," "gross" or "fragrant." 34

Thus, there may be continuing violations through a series of actions or omissions by a state related to the same case which taken as a whole represent the position of a state in that particular case. In Agrotexim and Others v. Greece case the ECtHR accepted that a series of events may constitute a continuing breach of the Convention considering the successive actions of Athens Municipal Council amounting to a continuing violation, ${ }^{35}$ even though the actions had been initiated before Greece ratified Protocol 1. The argument was based also on the fact that the expropriation was not an instantaneous act but rather consisted of a series of steps that continued until the protocol's entry into force. ${ }^{36}$ Similarly, in Phocas $v$ France case the applicant was unable to formally use his property under a threat of expropriation of his land during a period of about 15 years which was recognized as a factual situation having continuing nature. ${ }^{37}$

Thus, there are instances when continuing violations of human rights is apparent (the continuing illegal prevention to possess and enjoy property or join families, not enforce a person's right to see his/her child, execute a judgment in the applicant's favor, etc.). Similarly, instantaneous acts can also be easily detectable when violations are executed immediately and are not accompanied with lasting effects (e.g. killing, destruction of moveable property, killing). Problem arises in respect of cases with continuing negative consequences. In this case, if negative consequences by themselves, without reference to the causing act, do not qualify as breaches of the Convention (e.g. pain resulting from a single act of assault) then there is no "continuing violations." However, in cases when the lasting consequences or effects of an instantaneous act are themselves contrary to the Convention, such cases can be considered as continuing situations/violations (e.g. unlawful detention which is a result of unlawful arrest; unlawful possession of someone's' property which is a result of unlawful confiscation). ${ }^{38}$

Consequently, if an act of confiscation is unlawful and incompatible with the rights

32 Bottazzi v. Italy, no.34884/97, Judgement, 28 July1999, para. 22.

33 See the Report of the Commission in the case of Cyprus v Turkey, appl. no. 80007/77, DR72, p. 6.

34 Loukis Loucaides, The European Convention on Human Rights. Collected Essays, Nijhoff Law Specials, Vol.

70 (Leiden, Boston: Brill/Nijhoff, 2007), 17.

35 Agrotexim and Others v. Greece, no. 14807/89, Judgement, 24.10.1995, para.58.

36 Ibid.; Loucaides, The European Convention on Human Rights, 20.

37 Phocas v. France, no. 17869/91, Judgement, 23.04.1996.

38 Loucaides, The European Convention on Human Rights, 19-20. 
protected by the Convention, the future deprivation can be considered as a continuing breach of the right of peaceful enjoyment of property. Similarly, if the original act of "deprivation" of a property was illegal the keeping of the property by the State by virtue of such an act amounts to a continuing interference or unlawful keeping of confiscated property. In such circumstances the government should be accountable during all the period which has elapsed since the original act of deprivation. The ECtHR case law demonstrates that the time element is not a deterrent in such cases.

The test of whether violations are continuing in cases that originate from an initial instantaneous act are composed of the following factors:

- the nature of the complaint (the particular act or conduct that is alleged to be a violation);

- the effects of the complained conduct or act on the applicant's right;

- the duration of abovementioned effects;

- the prolongation of the operation of the relevant conduct or act or the maintenance of the effects via the conduct or involvement of the State. ${ }^{39}$

\section{Armenian Confiscated Properties: A Brief Analysis of Turkish Laws}

The overall process of confiscation of the Armenian properties and their legitimization began in 1915 and continued to the present being a direct consequence of the Armenian Genocide. A long sequence of laws, orders and decrees has been passed to initiate, manage and resume the process, starting with the Temporary law of deportation of Armenians on 27 May 1915, a secret order informing the local government about the management of the Armenian properties immediately after the deportation decision on 10 June 1915; 13 September 1915, the Ottoman parliament passed the "Temporary Law of Expropriation and Confiscation, "Temporary law" of 27 September 1915 titled "The law about the abandoned properties, debts and credits of the population who were sent elsewhere"; 8 November 1915 Regulation regarding the practice of the items of the 27 September law and modification of the Armenian Constitution of 1863 by the on 11 August $1916 .{ }^{40}$ This was the first phase of initiation and implementation of confiscation process. After the defeat of the Ottoman Turkey in WWI, the new government and parliament have rejected the laws on deportation and abandoned properties as violating the Ottoman Constitution. Moreover, by 8 January 1920 decree, the Istanbul government protected the rights of original owners of the confiscated properties. ${ }^{41}$

This course was soon reverted by the Ankara government established by nationalistic forces and on 7 June 1920 the Grand National Assembly of Turkey adopted a law invalidating the political and commercial treaties of the Istanbul government thus legalizing and legitimizing the liquidation of the Armenian properties. This was followed by series of laws and decrees that reach till 2011 (Law of 20 April 1922; decree of 12 March 1922; Law of 15 April 1923; decree issued on 28 June 1923; Law on the abandoned properties

39 Loucaides, The European Convention on Human Rights, 33.

40 Üngör and Polatel, Confiscation and Colonization, 41-47.

41 Ibid., 48-49. 
of 13 March 1924; the decree of 15 July 1925 on abolishing bank account deposit (bakiye) of the missing persons; the government ordinance of 13 June 1926 on necessity to seize the abandoned properties; the governmental decree of 17 July 1927; the Assembly decision on 2 June 1929; Governmental law of exclusion of Turkish nationality from those who had not taken part in the War of Independence, had remained abroad between 1923-1927; the 1935 Law on Religious Foundations and its amendments made in 2002, 2003, and 2008; ${ }^{42}$ the Constitution of Turkey; the General Directorate of Land Registry and Cadaster's circular order on confiscation by the state of the abandoned properties on 29 June 2001 and Prime Minister's Decree of 27 August 2011.

Thus, there is a clear pattern of consequent actions aimed at legalizing the unlawful confiscations.

The analysis of Turkish laws and administrative practice by Taner Akcam, ${ }^{43}$ Uğur Ümit Üngör and Mehmet Polatel, ${ }^{44}$ as well as Sait Cenitoglu ${ }^{45}$ clearly demonstrated that confiscation of the Armenian properties, later refusal to provide remedy, to return them to their real owners or pay compensation, accepted administrative practice and obstacle to apply to the Turkish Courts, hindering and not allowing details about confiscated properties deeds and other information is an example of mix of complex acts and composite acts (like Italian cases) with aggravating effects.

Particularly, since the adoption of first decrees, laws and decisions regarding Armenians confiscated properties, Ottoman Empire, and later the Turkish Republic has created all the possible difficulties for Armenians to return to get their properties back or to get compensation.

At first, before deportation Armenians were not allowed to sell their properties and take money from the banks. Then the properties of those people, who managed to escape from genocide were abandoned. ${ }^{46}$ After 1924 those people who were absent from Turkey for different reasons, were deprived of Turkish citizenship and thus could not any more return and get their properties back. ${ }^{47}$ Several people managed with the difficulties with international passport to return to Turkey in 1920's to get their properties back or to get compensation; however they were arrested and expelled. ${ }^{48}$ Those people who stayed in Turkey were forced to refuse from their rights to claim their properties, to claim to protect their right under Lausanne Treaty. Later on in September 1923 the return of those Armenians who left Turkey during the war was banned. ${ }^{49}$

Even those Armenians, who were escaped to Syria and Lebanon, tried to get their prop-

42 http://ncwarmenians.org/LawsDecrees, accessed 12.05.2018; Üngör and Polatel, Confiscation and Destruction, $41-59$.

43 Taner Akçam, "The Spirit of the Law: Following the Traces of Genocide in the Law of Abandoned Property," International Criminal Law Review 14 (2014) 377-395

44 Üngör and Polatel, Confiscation and Destruction, 41- 59

45 Sait Çetinoðlu, "Foundations of Non-Muslim Communities: The Last Object of Confiscation," International Criminal Law Review 14 (2014): 396-406.

46 http://ncwarmenians.org/LawsDecrees.

47 Ibid.

48 Çetinoğlu, "Foundations of Non-Muslim Communities," 398-399.

49 Ibid., 399. 
erties back or to get compensation through the French government as a mandatory of Syria and Lebanon. In 1924 the French government began negotiations with Turkey for compensation of Lebanese and Syrian Rum-Orthodox people, and Armenian tried to include their properties issue, too. Despite the agreement from the French side, Turkey refused including the Armenian reparation issue, threatened France to stop negotiations, and finally French-Turkey agreement was concluded without a mention to the Armenians properties issue..$^{50}$

The abandoned property laws were abolished only 73 years later, on 11 June 1986 . The abolishment of the law, however, does not mean that the liquidation process has stopped. The General Directorate of Land Registry and Cadaster on 29 June 2001 published a circular order about the abandoned properties, according to which all abandoned properties had transferred to the state. Also, it was made impossible to give any title deed, information or document to anyone. This indicates that Armenian property had ultimately been transferred to the state. ${ }^{51}$ For the real owners or their heirs it was nearly impossible to claim any rights to their properties according to Turkish law.

Furthermore, the 1935 Law on Religious Foundations was amended several times (in 2002, 2003, and 2008), allowing religious foundations in very limited circumstances and only with the approval of the General Directorate of Foundations to gain property and apply for the return of confiscated property. The effect of these amendments was limited, and the vast majority of such applications were denied.

On 27 August 2011, the then Prime Minister of Turkey Recep Tayyip Erdoğan announced a new decree (the Decree) that "communities whose properties had been expropriated by the state could apply for the properties to be returned, or to receive compensation for properties that had been sold to third parties. The Decree also permitted the formation of new religious community foundations to account for oversights in the 1935 foundations law and the reopening of foundations that previously had been closed and administered by the GDF." ${ }_{52}$ The Decree covered "(i) properties surveyed and registered in 1936 and subsequently confiscated from the religious foundations by various administrations of the Republic of Turkey; (ii) cemeteries belonging to non-Muslim foundations which had been improperly placed under the control and management of various towns and municipalities; and (iii) undefined deeded property (such as monasteries, parishes, and schools), which were never recognized as legal entities by the Turkish Republic." 53

In its review of the Decree of 2011 the Organization for Security and Cooperation in Europe (OSCE) concluded that the process has been challenging, flawed, and at times illusory, identifying the following problems:

50 For more on this issue see Vahé Tachjian, “An Attempt to Recover Armenian Properties in Turkey through the French Authorities in Syria and Lebanon in the 1920s," International Criminal Law Review 14 (2014): 396-406, 350-355, Üngör and Polatel, Confiscation and Destruction, 41- 59.

51 http://ncwarmenians.org/LawsDecrees.

52 Tolerance and Non-Discrimination II Combating Discrimination against Christians," at http://www.osce. org/odihr/124651?download=true, accessed 15.06.2019.

53 Ibid. 
- The Decree covered only very limited number of properties, omitting several thousands;

- One year time limit for the submission of the applications was not sufficient;

- The Decree was intended only for foundation;

- The application process was also flawed, as was being administered by the GDF, the same office that seized those property;

- The majority of cases were rejected without any explanation;

- The process of appeal was also flawed as was heard by the same officials who had already denied the applications;

- The Ministry of Finance Ministry was the only body to decide the size of compensation, which as a state institution was interested in reducing the amounts;

- There were also problems with the management of the foundations caused by the Turkish Government putting the ability of foundations to sustain the returned properties under a risk. ${ }^{54}$

In his paper on "Foundations of Non-Muslim Communities: The Last Object of Confiscation" Sait Çetinoðlu concludes that "while on the surface there might appear to be some positive movement regarding properties confiscated from non-Muslim foundations in Turkey, this is undermined by the reality of the difficulty of pursuing recovery cases and the many exclusions from the laws appearing to allow for recovery. It is further possible to say that confiscation has been legally normalized and continues to be acceptable, as part of a long-term property expropriation process targeting non-Muslim minorities in Turkey and contributing to their communities dissolution. " 55

Thus, there is a clear series of composite acts first by the Ottoman Empire than by the Republic of Turkey that aimed at confiscating and legalizing the Armenian properties. Meanwhile, it is also obvious that there was and is a really serious administrative practice and obstacle for getting effective remedy for Armenian properties.

\section{Conclusion}

Thus, ratione temporis jurisdiction of ECtHR covers only the period after the ratification of Convention or its Protocols by States. However, Convention institutions have accepted the extension of their jurisdiction ratione temporis to situations involving a continuing violation which originated before the entry into force of the Convention but persisted after that date. The analysis provided in this article demonstrates that it must be shown continuing violation/situation, in order to apply retroactive jurisdiction of ECtHR.

The application of the continuing violation/situation test provided in this article to the Armenian properties case confiscated during the Armenian Genocide shows that ECtHR could accept the possible cases from the heirs of Armenian genocide survivors and consider those cases admissible ratione temporis.

54 "Tolerance and Non-Discrimination II Combating Discrimination against Christians."

55 Çetinoðlu, "Foundations of Non-Muslim Communities," 406. 


\section{Acknowledgment}

This work was made possible by a research Grant (HU-hist-1289) from the Armenian National Science and Education Fund (ANSEF), based in New York, USA. 